\title{
Pulmonary gas transfer 20 years after pneumonectomy for pulmonary tuberculosis
}

\author{
F. GIMENO ${ }^{1}$, J. K. KRAAN ${ }^{1}$, N. G. M. ORIE ${ }^{2}$, AND R. PESET ${ }^{2}$ \\ From the Department of Lung Diseases and Lung Function Laboratory, Beatrixoord Haren \\ (Groningen) ${ }^{1}$, and the Department of Lung Diseases, Medical Department, University Hospital, \\ Groningen ${ }^{2}$, The Netherlands
}

Gimeno, F., Kraan, J. K., Orie, N. G. M., and Peset, R. (1977). Thorax, 32, 80-83. Pulmonary gas transfer 20 years after pneumonectomy for pulmonary tuberculosis. The changes in pulmonary function after pneumonectomy in 13 patients with pulmonary tuberculosis have been studied. The data at the time of two follow-up studies are compared with those obtained before the pneumonectomy. The first follow-up was carried out between 5 and 30 months postoperatively and the second between 20 and 24 years later. The results of this second follow-up show a relatively normal arterial oxygen saturation and gas transfer factor but an increased residual volume which cannot be explained by increasing age alone.

The influence of thoracic surgery and pulmonary resection on pulmonary function in tuberculosis patients has been extensively studied in the past (Cournand et al., 1950; Geelen, 1953; Laros, 1956; Larmi et al., 1959; Dietiker et al., 1960; Pianetto et al., 1967). Changes in lung function after pneumonectomy were evaluated by comparing pre- and post-operative results in the same patients and by comparing these results with the predicted values. These published data described the influence of this operation on pulmonary function during the immediate postoperative period. Some publications compared the values for gas transfer factor preoperatively and one to 10 months postoperatively (Dietiker et al., 1960), but few are available on lung function many years after the operation. Laros studied lung volumes soon after pneumonectomy (Laros, 1956; Tammeling and Laros, 1959) and again 20 years after the operation (Laros, 1973). In the present paper, the lung volumes, blood gas values, and gas transfer factors of a group of 13 patients who underwent pneumonectomy about 20 years ago are presented.

\section{Patients}

The present study concerns 13 patients, four women and nine men, who underwent pneumonectomy for tuberculosis between 1947 and 1954. Ventilatory tests were performed before and again shortly after the operation. The tim民ึ between operation and the last lung function assessment, including the determination of ga $\overrightarrow{\mathrm{S}}$ transfer factor, ranged from 20 to 24 (mean 21.4 years. The age of the patients at the time of thi last investigation ranged from 42 to 60 (mean $51 \cdot 2$. years, height from 156 to 190 (mean 176.2) cm and weight from 57 to 95 (mean 78.9) $\mathrm{kg}$. Fug details concerning the individual patients may be obtained from the authors on request.

\section{Methods}

The following pulmonary function studies were carried out in the sitting position:

Spirometry The slow inspiratory vital capacity and forced expiratory volume in one second measure with a water-sealed spirometer.

Lung volumes Residual volume was determined by the closed-circuit helium dilution metho (Tammeling, 1958). Predicted values were obtainet from Tammeling (1961). In 10 patients, pree operative bronchospirometry was also carried oup (Tammeling, 1958).

Arterial blood gases In three cases arteriat oxygen saturation at discharge after pneumonec. tomy was measured with the reflection metho according to Zijlstra (1951). Twenty years afte? pneumonectomy arterial blood gases were measured using glass and membrane electrodese 
The arterial oxygen saturation was calculated from the $\mathrm{pH}$ and $\mathrm{PaO}_{2}$ in blood (Severinghaus, 1966). In our experience, both methods, the reflection and the calculated saturation, give comparable values for arterial oxygen saturation (Gimeno, 1969).

Pulmonary diffusing capacity The pulmonary diffusing capacity was measured at rest by the carbon monoxide single breath method according to Ogilvie et al. (1957) with some modifications (Peset and Gimeno, 1974). Predicted values were obtained from Cotes (1965).

\section{Results and discussion}

A summary of the results is given in Table 1. After pneumonectomy the vital capacity decreased to a greater extent than the residual volume. The mean forced expiratory volume in the first second after a maximal inspiration was reduced to about the same extent as the vital capacity. The residual volume increased with the years to postoperative values which are larger than the preoperative ones. These observations are in agreement with those of Laros (1956) and Burrows et al. (1960).

It is of interest that the arterial blood oxygen saturation increased in the three patients tested before and 20 years after pneumonectomy. Arterial blood carbon dioxide tension values did not change (mean value $4.5 \mathrm{kPa}$, range $3 \cdot 7-5 \cdot 3$ ).

Table 2 gives the values for gas transfer. About 20 years after operation the mean gas transfer factor represents about $78 \%$ (range 47 to 104) of the predicted value for two lungs, and the mean Krogh's permeability coefficient about $110 \%$ of the predicted value (range 60 to 143).

The forced expiratory volume in the first second decreased to the same extent as the vital capacity so that the percentage of the vital capacity which can be expired in one second was not affected by pneumonectomy. The small changes observed can be explained by the increasing age of the group (Greifenstein et al., 1952). The volume

Table 1 Average function studies before and after pneumonectomy in 13 patients

\begin{tabular}{|c|c|c|c|}
\hline & Before operation & $\begin{array}{c}\text { At discharge } \\
\text { (5 to } 30 \mathrm{mth} \text { postop.) }\end{array}$ & $\begin{array}{c}\text { Follow-up } \\
(20-24 \text { yr postop.) }\end{array}$ \\
\hline $\begin{array}{l}\text { Vital capacity (litres BTPS) } \\
\text { Vital capacity ( } \% \text { of predicted) } \\
\text { Residual volume (litres BTPS) } \\
\text { Residual volume ( } \% \text { of predicted) } \\
\text { Total lung capacity ( } \% \text { of predicted) } \\
\text { Forced expiratory volume in one second (litres BTPS) } \\
\text { Forced expiratory volume in one second ( } \% \text { of predicted) } \\
\text { Arterial oxygen saturation }(\%)\end{array}$ & $\begin{array}{l}3 \cdot 45(0 \cdot 93) \\
68 \cdot 0(13 \cdot 7) \\
1 \cdot 20(0 \cdot 32) \\
91 \cdot 5(15 \cdot 3) \\
70 \cdot 5(11 \cdot 1) \\
2 \cdot 27(0 \cdot 56) \\
73 \cdot 2(15 \cdot 9) \\
\quad-\end{array}$ & $\begin{array}{l}2 \cdot 44(0 \cdot 69) \\
48 \cdot 0(13 \cdot 0) \\
1 \cdot 17(0 \cdot 50) \\
89 \cdot 0(21 \cdot 5) \\
55 \cdot 0(9 \cdot 9) \\
1 \cdot 54(0 \cdot 40) \\
50 \cdot 3(11 \cdot 7) \\
95 \cdot 0(3 \cdot 6)\end{array}$ & $\begin{array}{l}2 \cdot 37(0 \cdot 60) \\
50 \cdot 0 \quad(9 \cdot 9) \\
1 \cdot 86(0 \cdot 81) \\
93 \cdot 8(33 \cdot 5) \\
64 \cdot 2(15 \cdot 6) \\
1 \cdot 39(0 \cdot 29) \\
46 \cdot 4(12 \cdot 2) \\
96 \cdot 2(1 \cdot 2)\end{array}$ \\
\hline
\end{tabular}

Figures in parentheses represent standard deviations.

Table 2 Pulmonary diffusing capacity data in 13 patients 20 years after left pneumonectomy

\begin{tabular}{|c|c|c|c|c|}
\hline Subject & $\begin{array}{l}\text { Diffusing capacity } \\
\left(\text { mmol min }^{-1} \mathrm{kPa}^{-1}\right)\end{array}$ & $\begin{array}{l}\text { Diffusing capacity } \\
\text { ( } \% \text { of predicted } \\
\text { for both lungs) }\end{array}$ & $\begin{array}{l}\text { Krogh's coefficient } \\
\left(\mathrm{mmol} \mathrm{min}^{-1} \mathrm{kPa}^{-1} l^{-1}\right)\end{array}$ & $\begin{array}{l}\text { Krogh's coefficient } \\
\text { ( } \% \text { of predicted } \\
\text { for both lungs) }\end{array}$ \\
\hline $\begin{array}{l}\text { AvL } \\
\text { JLK } \\
\text { JM } \\
\text { LSW } \\
\text { AMH } \\
\text { JO } \\
\text { RK } \\
\text { HM } \\
\text { JK } \\
\text { JH } \\
\text { BB } \\
\text { KG } \\
\text { ABW }\end{array}$ & $\begin{array}{r}10.3 \\
6.0 \\
5.7 \\
7.5 \\
4.0 \\
8.7 \\
7.0 \\
8.5 \\
8.3 \\
8.4 \\
8.3 \\
6.5 \\
6.9\end{array}$ & $\begin{array}{r}100 \\
78 \\
55 \\
104 \\
47 \\
93 \\
71 \\
76 \\
84 \\
83 \\
80 \\
57 \\
90\end{array}$ & $\begin{array}{l}1.43 \\
1.36 \\
1.86 \\
2.03 \\
1.68 \\
2.13 \\
2.02 \\
2.23 \\
2.25 \\
1.85 \\
1.87 \\
0.95 \\
2.45\end{array}$ & $\begin{array}{r}99 \\
81 \\
120 \\
115 \\
99 \\
140 \\
143 \\
143 \\
136 \\
120 \\
126 \\
60 \\
140\end{array}$ \\
\hline $\begin{array}{l}\text { Mean } \\
\text { Standard deviation }\end{array}$ & $\begin{array}{l}7 \cdot 4 \\
1 \cdot 6\end{array}$ & $\begin{array}{l}78 \cdot 3 \\
17 \cdot 3\end{array}$ & $\begin{array}{l}1 \cdot 85 \\
0.41\end{array}$ & $\begin{array}{r}117 \cdot 0 \\
25 \cdot 9\end{array}$ \\
\hline
\end{tabular}

Conversion: SI to traditional units:

Diffusing capacity $1 \mathrm{mmol} \mathrm{min}{ }^{-1} \mathrm{kPa}^{-1} \approx 2.99 \mathrm{ml} \mathrm{min}-1$ torr-1.

Krogh's coefficient $1 \mathrm{mmol} \mathrm{min}^{-1} \mathrm{kPa}^{-1} 1^{-1} \approx 2.99 \mathrm{ml} \mathrm{min}^{-1}$ torr $^{-1} 1^{-1}$. 
expired in one second in relation to the total lung capacity was significantly decreased, which is in accordance with the observations of Hirdes and Bosch (1955), Laros (1956), Tammeling and Laros (1959), and Burrows et al. (1960).

After pneumonectomy the residual volume decreased only slightly and not as much as the vital capacity. In the follow-up studies the residual volume was found to increase from 89 to $94 \%$ of the predicted values for both lungs. Tammeling and Laros (1959) and Burrows et al. (1960) recorded a progressive increase in residual volume after pneumonectomy for tuberculosis: and this was of greater degree than that observed in the present study.

The arterial blood gases measured 20 years after pneumonectomy are of interest. Arterial oxygen tension values were higher (mean 11.7 $\mathrm{kPa}$ ) than those given by Ulmer and Reichel (1963) and Sorbini et al. (1968) for healthy adults of the same age (mean $10.8 \mathrm{kPa}$ ), while arterial carbon dioxide tension values were normal. When arterial oxygen saturation was calculated using the data provided by the electrodes in the three patients whose arterial saturation was measured after discharge with a haemoreflector, it was seen that 20 years later oxygen saturation was higher. That in these three patients oxygen saturation did not change with age can be explained by assuming that the progressive increasing inequality of ventilation/perfusion ratios with age, responsible for the reported decreased arterial tension in elderly patients (Holland et al., 1968) did not take place.

Dietiker et al. (1960) found in patients who underwent pneumonectomy for tuberculosis that six months after the operation the decrease in gas transfer factor, measured by the single breath method, was identical with the decrease in total lung capacity. This close relationship between volume and diffusion does not seem to apply many years after operation. In our patients, the total lung capacity expressed as percentage of the predicted values changed from $70 \%$ before the operation to about $55 \%$ about 10 months after pneumonectomy, and to $64 \%$ about 20 years after pneumonectomy. And at this time, 20 years after operation, we found that the mean gas transfer factor is almost $80 \%$ of the predicted value for both lungs, and not $64 \%$ as would be expected from Dietiker's data.

This suggests that the remaining lung can partially take over the function of the removed lung, and that the decrease in transfer factor due to aging, as shown by Forster (1957), might be compensated by the physiological changes which follow pneumonectomy. Unfortunately, no trans- - ․ㅡㄹ fer factor determinations were performed before $\frac{\rho}{-}$ or shortly after the operation since at that time (1947 to 1955) facilities for measuring it were not available. However, the normal arterial $\vec{\circ}$ oxygen tension, the high pulmonary transfer: factor as well as the high Krogh's diffusion coeffi- $\vec{\omega}$ cient can be explained by a relative increase in diffusing surface. This is in keeping with the $x$ findings of Ogilvie et al. (1963), who reported that the transfer factor was well sustained 10 yearsafter pneumonectomy for carcinoma. Possibly thiso is achieved by perfusing the remaining lung witho the total cardiac output, thus keeping the ventila-tion/perfusion ratio at an optimal level.

We thank Dr. C. D. Laros, of the Department of Lung Diseases, St. Antonius Hospital, Utrecht, The Netherlands, for permission to study hise patients. We also thank Professor Dr. H. J. . Sluiter, of the Department of Lung Diseases, 0 State University, Groningen, The Netherlands, and Dr. C. D. Laros for providing helpfuP criticism during the preparation of the manuscript

\section{References}

Burrows, B., Harrison, R. W., Adams, W. E., Humphreys, E. M., Long, E. T., and Reimann A. F. (1960). The postpneumonectomy state. Clinical. and physiologic observations in thirty-six cases American Journal of Medicine, 28, 281-297.

Cotes, J. E. (1965). Lung Function. Blackwell, Oxford

Cournand, A., Riley, R. L., Himmelstein, A., and Austrian, R. (1950). Pulmonary circulation an alveolar ventilation-perfusion relationships afte pneumonectomy. Journal of Thoracic Surgery, 19:3ํำ 80-116.

Dietiker, F., Lester, W., and Burrows, B. (1960). The effects of thoracic surgery on the pulmonary diffuse ing capacity. American Review of Respiratory Diseases, 81, 830-838.

Forster, R. E. (1957). Exchange of gases betweeñ alveolar air and pulmonary capillary blood: pulD monary diffusing capacity. Physiological Reviewsiv 37, 391-452.

Geelan, E. E. M. (1953). Longfuncties na longresectie Thesis, Groningen University, The Hague.

Gimeno, F. (1969). Clinical blood gas analysise Thesis, Groningen University. V.R.B.-Offset drukkerij, Groningen.

Greifenstein, F. E., King, R. M., Latch, S. S., an Comroe, J. H., Jr. (1952). Pulmonary functiof studies in healthy men and women 50 years and older. Journal of A pplied Physiology, 4, 641-648. 무

Hirdes, J. J. and Bosch, M. W. (1955). Pneumonecg tomy in pulmonary tuberculosis without thorace 
plasty. Clinical results and lung function studies. Journal of Thoracic Surgery, 30, 719-740.

Holland, J., Milic-Emili, J., Macklem, P. T., and Bates, D. V. (1968). Regional distribution of pulmonary ventilation and perfusion in elderly subjects. Journal of Clinical Investigation, 47, 81-92.

Larmi, T. K. I., Turunen, M., and Heinonen, A. O. (1959). The loss of pulmonary function, especially of pulmonary diffusing capacity, following some thoracic operations. Scandinavian Journal of Clinical and Laboratory Investigations, 11, 20-29.

Laros, C. D. (1956). De prognose van de pneumonectomie patiënt. Thesis, Groningen University, Groningen, The Netherlands.

Laros, C. D. (1973). Changes of vital capacity in 20 years after pneumonectomy (Abstract). Bulletin de Physio-pathologie Respiratoire, 9, 1240-1241.

Ogilvie, C. M., Forster, R. E., Blakemore, W. S., and Morton, J. W. (1957). A standardized breathholding technique for the clinical measurement of the diffusing capacity of the lung for carbon monoxide. Journal of Clinical Investigations, 36, 1-17.

Ogilvie, C. M., Harris, L. H., Meechan, J., and Ryder, G. (1963). Ten years after pneumonectomy for carcinoma. British Medical Journal, 1, 1111-1115.

Peset, R. and Gimeno, F. (1974). Medida del factor de transferencia (capacidad de difusion pulmonar) con monoxido de carbono segun la technica de respiracion unica. Archivos de Bronconeumologia, 10, 22.

Pianetto, M. B., Harris, H. A.. and Sweet, H. C.
(1967). Changes in pulmonary function before and after pneumonectomy for pulmonary tuberculosis. American Review of Respiratory Disease, 95, 189199.

Severinghaus, J. W. (1966). Blood gas calculator. Journal of Applied Physiology, 21, 1108-1116.

Sorbini, C. A., Grassi, V., Solinas, E., and Muiesan, G. (1968). Arterial oxygen tension in relation to age in healthy subjects. Respiration, 25, 3-13.

Tammeling, G. J. (1958). Het residual volume en de functionele residuaal capaciteit. Thesis, Groningen University, Assen.

Tammeling, G. J. (1961). Standard values for lung volumes and ventilatory capacity of sanatorium patients. Selected papers of the Royal Netherlands Tuberculosis Association, 1, 65.

Tammeling, G. J. and Laros, C. D. (1959). An analysis of the pulmonary function of ninety patients following pneumonectomy for pulmonary tuberculosis. Journal of Thoracic Surgery, 37, 148-165.

Ulmer, W. T. and Reichel, G. (1963). Untersuchungen über die Altersabhängigkeit der alveolären und arteriellen Saurstoff- und Kohlensäuredrucke. Klinische Wochenschrift, 41, 1-6.

Zijlstra, W. G. (1951). Fundamentals and applications of clinical oximetry. Thesis, Groningen University, Van Gorcum, Assen.

Requests for reprints to: Dr. F. Gimeno, 'Beatrixoord', Haren (Gr.), The Netherlands. 